Published in final edited form as:

Tetrahedron Lett. 2017 December 13; 58(50): 4717-4720. doi:10.1016/j.tetlet.2017.11.007.

\title{
Synthesis of $\mathbf{N}$-alkoxy-substituted $\mathbf{2 H}$-benzimidazoles
}

\author{
Nurul H. Ansari and Björn C. G. Söderberg \\ C. Eugene Bennett Department of Chemistry, West Virginia University, Morgantown, West Virginia \\ 26506-6045, United States
}

\begin{abstract}
Treatment of 2-nitro- $N$-(2-methyl-1-propen-1-yl)benzenamines with potassium tert-butoxide in tert-butanol followed by the addition of an electrophile affords $\mathrm{N}$-alkoxy- $\mathrm{H}$-benzimidazoles. Electrophiles including methyl iodide, allylic bromides, propargylic bromides, benzyl bromide, and acetyl chloride gave good to excellent yields of product while 1-iodo- and 2-iodo-butane afforded very low yields.
\end{abstract}

\section{Graphical Abstract}

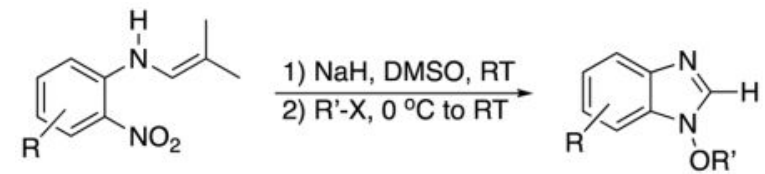

\section{Introduction}

$N$-alkoxy- and $N$-hydroxy-benzimidazoles have been shown to exhibit a number of biological activities such as, acting as a growth inhibitor of Lactobacillus leichmanii ${ }^{1}$ and influenza virus, ${ }^{2}$ inhibition of bacterial transcriptase factors, ${ }^{3}$ and anti-HIV-1 activity. ${ }^{4}$ Only two general methods for the preparation of $N$-alkoxybenzimidazoles can be found in the literature. The first method involves a direct alkylation of $N$-hydroxybenzimidazole, or its tautomer $1 H$-benzimidazole-3-oxide, and this procedure has been used to prepare, for example, $N$-methoxy, $N$-ethoxy and $N$-allyloxybenzimidazole. ${ }^{5}$ The second method reported by Gardiner et al is perhaps the most versatile synthesis of $N$-alkoxybenzimidazoles and it involves a base-mediated reaction of 2-nitroanilines in the presence of an alkyl halide (Scheme 1). ${ }^{6}$ A potential drawback is the formation of mixtures of $\mathrm{N}$-alkylated anilines and $\mathrm{N}$-alkoxybenzimidazoles observed in many cases. In addition, only a single case of an $\mathrm{N}$ alkoxy- $2 H$-benzimidazole was described.

Supporting Information

Supplementary information associated with this article including all experimental procedures and ${ }^{1} \mathrm{H}$ and ${ }^{13} \mathrm{C}$ NMR spectra of all novel compounds can be found in the online version, at http://dx.doixxxxxxxxx

Publisher's Disclaimer: This is a PDF file of an unedited manuscript that has been accepted for publication. As a service to our customers we are providing this early version of the manuscript. The manuscript will undergo copyediting, typesetting, and review of the resulting proof before it is published in its final citable form. Please note that during the production process errors may be discovered which could affect the content, and all legal disclaimers that apply to the journal pertain. 
We have recently developed a base-mediated cyclization-alkylation of 2-nitroaniline-derived enamines to afford $N$-alkoxy-substituted benzimidazoles having an oxygenate side chain in the 2-position. ${ }^{7}$ By simply changing the amount of base and electrophile used, either a hydroxy or an alkoxy substituent could be introduced on the side chain. For example, treatment of enamine 1 with 2.0 equivalents of sodium hydride $(\mathrm{NaH})$ in DMSO at ambient temperature followed by addition of 1.05 equivalents of methyl iodide (MeI) gave after purification $\mathrm{N}$-methoxybenzimidazole 2 (Scheme 2). When the amounts of both $\mathrm{NaH}$ and MeI were increased to 3.15 equivalents, $N$-methoxybenzimidazole 3 was isolated in good yield. In both reactions a very minor amount of $\mathrm{N}$-methoxy-2 $\mathrm{H}$-benzimidazole 4 was either isolated or observed in the crude reaction mixture. While optimizing the reaction conditions for a divergent synthesis of either $\mathbf{2}$ or $\mathbf{3}$, we found conditions wherein $\mathbf{4}$ was selectively formed (Scheme 2). Thus, reaction of $\mathbf{1}$ with potassium tert-butoxide in tert-butanol for $24 \mathrm{~h}$ followed by addition of methyl iodide gave $\mathbf{4}$ in $76 \%$ yield after chromatographic purification.

Herein we report the scope and limitations of the formation of $\mathrm{N}$-alkoxy- $2 \mathrm{H}$-benzimidazoles from reactions of enamines, derived from condensation of 2-nitroanilines with a-branched aldehydes, with reactive carbon-centered electrophiles.

\section{Results and Discussion}

Fifteen enamines $(\mathbf{1}, \mathbf{5}-\mathbf{1 8}$, Table 1) were prepared via condensation of 4- and 5-substututed 2-nitroanilines with 2-methylpropanal, 2-phenylpropanal, 2-cyclohexylethanal, and 2,2diphenylethanal in the presence of $4 \AA$ molecular sieves, as previously described. ${ }^{7}$ The basemediated transformation of enamines to afford $\mathrm{N}$-alkoxy- $2 \mathrm{H}$-benzimidazoles is limited by the availability of the starting material. It should be noted that we were unable to prepare enamines in synthetically useful yields from 3- or 6-substituted 2-nitroanilines even under more forced reaction conditions.

All enamines were treated with tert-BuOK in tert-BuOH followed by the addition of MeI under the reaction conditions depicted in Scheme 2. The expected cyclization-alkylation products, $\mathrm{N}$-methoxy- $2 \mathrm{H}$-benzimidazoles, were obtained in all but one case in $51-100 \%$ isolated yield. Cyclization-alkylation of both enamines having an electron-withdrawing ester (10) or nitro (11) group failed under the standard reaction conditions (entries 7 and 9). However, the ester-substituted enamine $\mathbf{1 0}$ was transformed to the corresponding $N$ methoxy- $2 H$-benzimidazoles $\mathbf{2 4}$ in god isolated yield using sodium hydride - MeI in dimethylsulfoxide as described previously. No conditions were found for the cyclization of 11, neither the starting material nor any identifiable product was isolated.

The scope and limitation of the electrophile was examined next using enamine $\mathbf{1}$ as the substrate and the results are summarized in Table 2. For all entries in Table 2, 1 was treated with potassium tert-butoxide for $24 \mathrm{~h}$ followed by the addition of an electrophile. High yields of $N$-alkoxy- $2 H$-benzimidazoles were obtained using benzyl bromide, allyl bromide and 2-methyl-3-bromopropene affording 29-31, respectively (entries 1-3). A 54\% yield of $\mathrm{N}$-acetoxy-2H-benzimidazole (34) was obtained using acetyl chloride while heptyl bromide, butyl iodide and 2-iodopropane gave cyclization products in low isolated yields. The two 
propargylic bromides employed in entries 4-5, 3-bromo-1-propyne and 3-bromo-1-butyne, afforded allenes by an $\mathrm{S}_{\mathrm{N}} 2^{\prime}$ reaction albeit, in low yields (entries 4-5). Based on the results shown in Tables 1-2, synthetically useful yields are obtained only from reactions of highly reactive alkylating reagents such as methyl iodide, benzyl bromide, and allylic bromides. Our observations parallels Gardiner's results where lower yields of product were isolated from reactions with hindered and less reactive electrophiles such as 2-methyl-1-iodopropane compared to primary iodides, benzylic bromides, allyl bromide. ${ }^{6}$

The transformation presented above affording $\mathrm{N}$-alkoxy- $2 \mathrm{H}$-benzimidazoles can mechanistically be rationalized as follows. Deprotonation of 5 would afford 38, one of several possible resonance forms (Scheme 3). 1,7-Electrocyclization of 38 would furnish 39 , followed by a ring opening to form the nitroso-imine 40. The two latter steps results in an overall intramolecular reduction - oxidation. 1,5-Electrocyclization of $\mathbf{4 0}$ to give $\mathbf{4 1}$ is plausible based on literature precedence. ${ }^{8}$ Aromatization of intermediate $\mathbf{4 1}$ via loss of acetone would furnish anion $\mathbf{4 2}$ which can finally be alkylated to give an $\mathrm{N}$-alkoxy-2 $\mathrm{H}$ benzimidazole 43. The mechanism outlined in Scheme 3 is supported by a limited number of related transformations described in the literature. ${ }^{9,10,11}$ Based on the mechanism outlined, not only is an $\mathrm{N}$-alkoxy-2 $\mathrm{H}$-benzimidazole formed but also acetone as a biproduct. While acetone (entries 1-13), acetophenone (entry 14), or cyclohexanone (entry 15) were not isolated from the reactions depicted in Table 1, an almost quantitative yield of benzophenone was obtained from 19 (entry 16). Neither of the three former byproducts were recovered after chromatographic purification. This is probably due to evaporative loss upon removal of solvents.

\section{Summary}

$\mathrm{N}$-Alkoxy-2 $\mathrm{H}$-benzimidazoles can be prepared from enamines derived from condensation of 4- or 5-substituted 2-nitroanilines and a-branched aliphatic aldehydes via a base mediated cyclization-alkylation sequence using potassium tert-butoxide and a reactive electrophile.

\section{Supplementary Material}

Refer to Web version on PubMed Central for supplementary material.

\section{Acknowledgments}

We gratefully acknowledge the C. Eugene Bennett Department of Chemistry and funding from the National Institutes of Health (1 R15 GM122002-01) for support. The National Science Foundation-MRI program is also gratefully acknowledged for the funding of a $400 \mathrm{MHz}$ NMR system (CHE-1228366). The authors would like to thank Dr. Gregory Donohoe and Dr. Mahdiar Khakinejad for HRMS analyses.

\section{References}

1. Wacker A, Weygand F. Z Naturforsch. 1952; 7b:488-489.

2. Tamm I, Folkers K, Shunk CH, Horsfall FL Jr. J Exp Med. 1954; 99:227-250. [PubMed: 13130796]

3. Bowser TE, Bartlett VJ, Grier MC, Verma AK, Warchol T, Levy SB, Alekshun MN. Bioorg Med Chem Lett. 2007; 17:5652-5655. [PubMed: 17766109]

4. Evans TM, Gardiner JM, Mahmood N, Smis M. Bioorg Med Chem Lett. 1997; 7:409-412. 
5. a) Popov II, Kryshtalyuk OV. Khim Getero Soedin. 1991:997-998.b) Stacy GW, Ettling BV, Papa AJ. J Org Chem. 1964; 29:1537-1540.c) Takahashi S, Kanio H. Chem Pharm Bull. 1964; 12:282291. [PubMed: 5888571] d) Takahashi S, Kanio H. Chem Pharm Bull. 1963; 11:1375-1381. [PubMed: 14090584]

6. a) Reference 4. Gardiner JM, Loyns CR, Schwalbe CH, Barrett GC, Lowe PL. Tetrahedron. 1995; 51:4101-4110.Gardiner JM, Loyns CR. Synth Commun. 1995; 25:819-827.

7. Ansari NH, Jordan AL, Söderberg BCG. Tetrahedron. 2017; 73:4811-4821.

8. A 1,5-electrocyclization was proposed in a synthesis of 2-phenyl-1-hydroxybenzimidazole from an in situ reaction of 2-nitrosoaniline and benzaldehyde. Nazer MZ, Haddadin MJ, Petridou JP, Issidorides CH. Heterocycles. 1977; 6:541-545.

9. Nyerges M, Viranyi A, Zhang W, Groundwater PW, Blasko G, Toke L. Tetrahedron. 2004; 60:99379944.

10. Nyerges M, Somfai B, Toth J, Toke L, Dancso A, Blasko G. Synthesis. 2005:2039-2045.

11. Banini SR, Turner MR, Cummings MM, Söderberg BCG. Tetrahedron. 2011; 67:3603-3611. 


\section{Research highlights}

- A synthetic methodology to $N$-alkoxy-2H-benzimidazoles was developed.

- $\quad$ Enamines derived from condensation of 2-nitroanilines and aliphatic aldehydes were cyclized under basic conditions were used as starting materials.

- The alkoxy-group could be varied by the use of different reactive organic halides. 


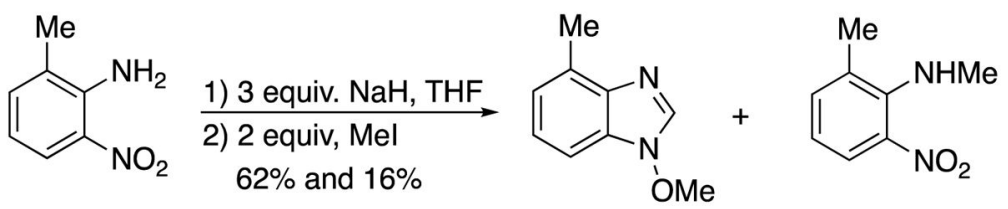

Scheme 1.

Gardiner et al synthesis of 1-methoxy-4-methylbenzimidazole. 


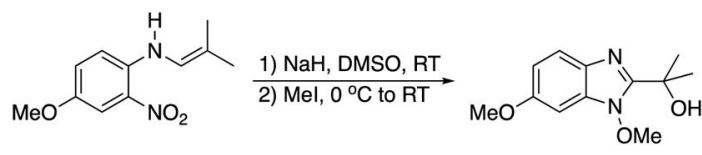

1) 2.0 equiv. $\mathrm{NaH}, 1 \mathrm{~h}, \mathrm{RT}$

2) 1.05 equiv. MeI, $1 \mathrm{~h}, 0{ }^{\circ} \mathrm{C}-\mathrm{RT}$

1) 3.5 equiv. $\mathrm{NaH}, 1 \mathrm{~h}, \mathrm{RT}$

2) 3.5 equiv. MeI, $1 \mathrm{~h}, 0^{\circ} \mathrm{C}-\mathrm{RT}$

1) 4 equiv. tert-BuOK/tert-BuOH, $24 \mathrm{~h}, \mathrm{RT} \quad 2(-)$

2) 3 equiv. MeI, $1 \mathrm{~h}, \mathrm{RT}$
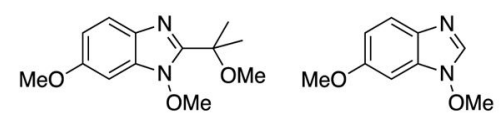

$2(74 \%)$

$3(-)$

$4(2 \%)$

$2(-)$

$3(71 \%)$

4 (trace)

$3(-)$

$4(76 \%)$

Scheme 2.

Cyclization of enamine $\mathbf{1}$ to give either $N$-methoxybenzimidazole $\mathbf{2}$ or $\mathbf{3}$. 


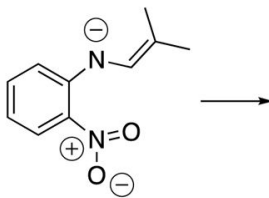

38

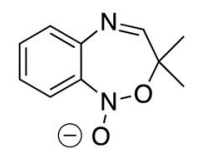

39

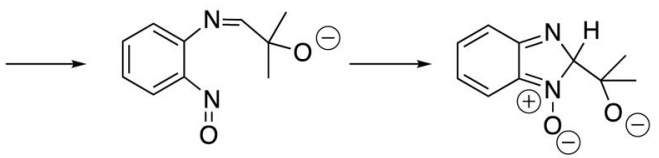

40

41

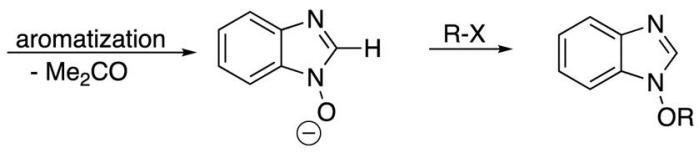

42

43

Scheme 3.

Proposed mechanism for the formation of $\mathrm{N}$-alkoxy- $2 H$-benzimidazoles. 


\section{Table 1}

Formation of $N$-methoxybenzimidazoles from 2-nitro- $N$-(2-methyl-1-propen-1-yl)benzenamines and methyl iodide.

\begin{tabular}{|c|c|c|}
\hline Entry & Enamine $^{a}$ & Methoxybenzimidazole $^{b}$ \\
\hline & & \\
\hline
\end{tabular}

$\begin{array}{ll}1 & \mathbf{5}(\mathrm{R}=\mathrm{H}) \\ 2 & \mathbf{1}(\mathrm{R}=4-\mathrm{OMe}) \\ 3 & \mathbf{6}(\mathrm{R}=4-\mathrm{Me}) \\ 4 & \mathbf{7}(\mathrm{R}=4-\mathrm{Cl}) \\ 5 & \mathbf{8}(\mathrm{R}=4-\mathrm{Br}) \\ 6 & \mathbf{9}(\mathrm{R}=4-\mathrm{F}) \\ 7 & \mathbf{1 0}\left(\mathrm{R}=4-\mathrm{CO}_{2} \mathrm{Me}\right) \\ 8 & \mathbf{1 0} c \\ 9 & \mathbf{1 1}\left(\mathrm{R}=4-\mathrm{NO}_{2}\right) \\ 10 & \mathbf{1 2}(\mathrm{R}=5-\mathrm{OMe}) \\ 11 & \mathbf{1 3}(\mathrm{R}=5-\mathrm{Me}) \\ 13 & \mathbf{1 5}(\mathrm{R}=5-\mathrm{Rl})\end{array}$

14

16<smiles>COc1ccc(NC=C2CCCCC2)c([N+](=O)[O-])c1</smiles>

$\begin{array}{ll}15 & \mathbf{1 7}\end{array}$<smiles>COc1ccc(NC=C(c2ccccc2)c2ccccc2)c([N+](=O)[O-])c1</smiles>

$19(100 \%)$

$4(76 \%)$

20 (76\%)

$21(92 \%)$

$22(85 \%)$

23 (67\%)

(not observed)

24 (74\%)

(not observed)

$25(85 \%)$

$26(71 \%)$

$27(71 \%)$

28 (73\%)<smiles>COn1cnc2ccc(Br)cc21</smiles>

22 (94\%)<smiles>COc1ccc2ncn(OC)c2c1</smiles>

$4(76 \%)$<smiles>COc1ccc2ncn(OC)c2c1</smiles>

$4(78 \%)^{d}$

${ }^{a}$ A solution of the enamine in tert-BuOH was treated with tert-BuOK ( 4 equiv.) stirred for $24 \mathrm{~h}$ then treated with $\mathrm{MeI}(3$ equiv.)

$b_{\text {Isolated yield of pure product after chromatography on silica gel. }}$

Tetrahedron Lett. Author manuscript; available in PMC 2018 December 13. 
${ }^{c}$ A solution of $\mathbf{1 0}$ in DMSO was treated with $\mathrm{NaH}$ (5 equiv.) stirred for $24 \mathrm{~h}$ then treated with MeI (5 equiv.) as described in reference 7.

${ }^{d}$ Benzophenone was also isolated in $97 \%$ yield. 
Table 2

Base mediated formation of $\mathrm{N}$-alkoxy-2H-benzimidazoles from enamine $\mathbf{1}$.

\begin{tabular}{llll}
\hline Entry $^{2}$ Enamine $^{\boldsymbol{a}}$ & Electrophile & \\
\hline & & \\
2 & $\mathbf{1}$ & Benzyl bromide & $\mathbf{2 9}(82 \%)$ \\
3 & & Allyl bromide & $\mathbf{3 0}(100 \%)$ \\
4 & 2-Methyl-3-bromopropene & $\mathbf{3 1}(90 \%)$ \\
6 & 3-Bromo-1-propyne & $\mathbf{3 2}(15 \%, \mathrm{R}=-\mathrm{CH}=\mathrm{C}=\mathrm{CH} 2)$ \\
7 & 3-Bromo-1-butyne & $\mathbf{3 3}(12 \%, \mathrm{R}=-\mathrm{CH}=\mathrm{C}=\mathrm{CHCH} 3)$ \\
8 & Acetyl chloride & $\mathbf{3 4}(54 \%)$ \\
9 & 1-Bromoheptane & $\mathbf{3 5}(16 \%)$ \\
\hline
\end{tabular}

${ }^{a}$ A solution of the enamine in $t$ - $\mathrm{BuOH}$ was treated with $t$-BuOK (4 equiv.), stirred for $24 \mathrm{~h}$ then treated with an electrophile ( 3 equiv.) $b_{\text {Isolated yield of pure product after chromatography on silica gel. }}$ 